\title{
The Access to and Use of ICT in Learning English: A Case of University Students
}

\begin{tabular}{ll}
\multicolumn{1}{c}{ Cici Adeliani ${ }^{1}$, Alamsyah Harahap ${ }^{2}$, Dedi Sofyan ${ }^{3}$, Ildi Kurniawan ${ }^{4}$ \& Azhar Aziz Lubis } \\
\end{tabular}

\section{Introducation}

In general, many students have problems in learning English (Kudsiyah, 2009). There are some factors causing learning problems to students. According to Syah (2005) cited in Kudsiyah (2009), causal factors of students' learning problems are divided into Internal and External factors. Internal factors include cognitive, affective and psychomotor. Meanwhile the external factors include family, society and school environment (e.g., school building condition, teacher and learning facility). Therefore, learning facilities can give a contribution to the learning process, especially in school.

Bafadal (2004) states that the learning facility is all of equipment, instruments or tools used to support the teaching learning process. Sabri \& Emuas (1999) says that according to some educational experts, five factors influencing the education process are teacher, learner, objective, tool and environment. In order to improve the result of learning, it will be effective if the learning facility is provided. Therefore, ICT (Information and communication technology) can be a learning facility.

ICT refers to the computer-based-technologies and internet-based technologies which are used for delivering and receiving the information (Annamalai, 2017). Ammanni \& Aparanjani (2016) state some hardware and software used for English language teaching and learning are e. g laptop, internet, e-books, audio books, Webinar, Interactive White Board (IWB), Mobile apps, Audio-visual aids, Over-head projectors/slides, tape recorder/gramophone, television, film projector, language laboratory, Web 2.0 applications and mobile phones. Therefore, ICT can be hardware and software.

Selinger (2000) and Al Arif (2019) state that Information and communication technology (ICT) has taken over teaching and learning around the globe nowadays. A group of ICT researcher claims that using ICT in teaching and learning will improve education and support teachers and learners more in teaching and learning (Westera \& Sloep, 2001). Many schools use ICT because it is practical, economic and easy to be used. It 
makes learning more interesting and easier to be implemented wherever and whenever (Sutrisno, 2012). Thus, ICT has been used in language teaching and learning.

Moreover, within Industry 4.0 Conditions, ICT is a must to be used in education (Lase, 2019). The concept of Industrial revolution 4.0 in education is characterized by the use of ICT in order to make the learning process take place continuously without space and time limitation. Therefore, ICT is important in this modern era.

Also, based on my own preliminary research (1 April 2020), it is found that ICT is commonly used in all educational sectors within the Covid-19 Pandemic nowadays. The school closures are due to COVID-19 in order to prevent infections caused by COVID-19. Therefore, the government creates a new education system innovation using ICT. It's called online teaching and learning. Thus, the approach and method of ICT are considered as an appropriate way to succeed the education purposes in this pandemic.

However, Siddiquah \& Salim (2017) state that students face problems while they are using ICT. The problems are poor working conditions of computers, lack of access to the Internet, non-availability of the required software, lack of technical support, virus threat, slow speed of computers, signal problem in the Internet and load shedding. Study from Nigeria showed that the lack of ICT resources and poor infrastructure prevent the full implementation of ICT in education (Adeosun, 2010). It means that students' environment affects the implementation of ICT.

Also, Siddiquah \& Salim (2017) state that another factor influencing the implementation of ICT is on students. Students have computers and Internet facilities at home and universities, but they spend more time on computers for recreational and other purposes than for academic purposes. Besides, students are expert at simple skills like MS Word, MS Power Point, Searching and Browsing at Internet, Social networking, Email, File attachment, and Computer games but are less skilled or poor on other skills like using digital library, discussion forums, and Blogs. It means that students' characteristics affect the implementation of ICT.

On the other hands, some recent research dealing with the use of ICT tools and applications in the field of English Language Teaching have been done by some researchers. For example, Al Arif (2019) found students' positive attitudes towards ICT use in learning English. Then, Alfarwan (2019) found ICT devices especially on electronic devices which are accessed and used by students in learning English. Siddiquah \& Salim (2017) also found students' access to ICT (computer and internet facilities) and problems faced by students while using ICT in University.

It can be seen that those previous studies just focus on students' attitude (positive or negative) and the students' access to ICT namely hardware and software in general), they haven't classified the examined ICT to more specific ICT devices which is ICT application related to English Language teaching and learning and the impact of ICT usage for students in mastering each English language skill.

Also, Margareta et al (2017) found that ICT media programs improve students' reading ability. Jariah et al., 2017 also state that ICT is effective for students mastering vocabulary. It is clearly seen that each previous research has different significance with this research. They haven't found out more about types of ICT applications accessed by English students and how far ICT application helps students in mastering overall English language skills in a single study.

Though similar research of ICTs use has been undertaken, but this research is different from others. This study is conducted in the University of Bengkulu with the participants being Undergraduate English Education Students. This current study focuses on students' access to ICT in learning English which refers to the ways of students to use ICT application related to English language teaching and learning in mastering English skill. Then, it focuses on how far the ICT application helps students in mastering English language skills which means to examine the impact of ICT application usage for students in mastering English language skills.

From the background above, the researcher wants to conduct a research entitled "English Education Students Access to and Use of ICT in Learning English: The Case of Bengkulu University?

\section{Literature Review}

\subsection{Students' Access to ICT}

Students' access means as students' opportunity to take full advantage of their education in using the schools' services in certain academic programs. This access is involved into access to technology. It includes highspeed internet connections and adequate hardware (computers, laptops, tablets) and software (particularly learning applications) so that students have equitable access to the same digital and online learning 
opportunities regardless of their family's income level or ability to pay for these technologies (Oxford University Press, 2016).

ICT refers to forms of technology that are used to transmit, process, store, create, display, share or exchange information by electronic devices. It includes such technologies as radio, television, video, DVD, telephone or mobile phones, satellite systems, and computer and network hardware and software, as well as the equipment and services associated with these technologies, such as video conferencing, e-mail and blogs (UNESCO, 2007).

\subsection{Benefits of ICT}

Some researchers found that ICTs are useful to improve students' ability in EFL learning. For instance, Margareta et al (2017) found that ICT media programs improve students' reading ability and Jariah et al (2017) also states that ICT is effective for students mastering vocabulary.

In addition to assisting students in English proficiency, ICTs also create the motivation enhancement (Schoepp \& Erogul, 2001). Both teachers and students feel ICT use greatly contributes to student motivation for learning. For example, placing computers/laptops in classrooms is a way to attract attention in the teaching learning process. Moreover, access outside of school affects user confidence. Students who use a computer at home also use them in school more frequently and with more confidence than pupils who have no home access.

Moreover, ICT also affects the learner independence Joshi \& Poudel, 2019). Evidence exists that use of ICTs can increase learner autonomy for certain learners. By using technology in their learning, the students can be active learners. They will be aware of what information they need, why they need it, and how they can get that information (Suryani, 2010).

It also gives the benefit in acquisition of skills (Galavis, 1998). ICT integration prepares learners for real-life situations (Lowther et al., 2008). Computer Aided (or Assisted) Instruction (CAI), which refers generally to student self-study or tutorials on PCs, has been shown to slightly improve student test scores on some reading, math skills, etc. ICT also improves students' literacy (Suryani, 2010).

Those make the process of teaching and learning easier and faster. The students may have opportunities to gain many materials. ICT tools and techniques are used to enhance teaching and learning opportunities more specifically remote learning resources (Al Arif, 2019).

\section{Method}

This research used an explanatory sequential mixed methods design which involved quantitative data through a questionnaire online survey and qualitative data by interview (Creswell, 2014).

The population of this research was all the students of English Department, Faculty of Education and Teacher Training at the University of Bengkulu. There were 80 students chosen as the sample to answer the questionnaire in this research from each different academic year $(2017,2018,2019,2020)$. There were 24 students from each different academic year $(2017,2018,2019,2020)$ as the sample to do the interview.

Both the questionnaire and interview consisted of 15 items which were adapted from Dang Hoang Tri and Nhung Hong Thi Nguyen (2014). The questionnaire was in google form, and interview was done through phone call. The question parts of the instruments were Personal Identification Data, Students' access to ICT application related to Esnglish teaching and learning and Students' perception. The validity and reliability were analyzed by Microsoft Excel.

The researcher counted the frequency and percentage of each item in questionnaire by using Microsoft Excel. After that, researcher interpreted the result of the questionnaire to get the answer of those two research questions. To support the answer of two research question, researcher analyzed the interview result by did the summary or paraphrase the students' answers from phone call, displayed the data in interview transcription, interpreted and concluded what are the meanings of data display correlated to study.

\section{Results and Discussion}

\subsection{The Results}

The researcher obtained the data for this research by using questionnaire and interview as the research instrument. This research has two research results namely students' access to ICT application and how far ICT application helps students in mastering English language skills. 
First, the researcher found that 15 types of ICT applications accessed by students of English Education Study Program at the University of Bengkulu. The data were collected from questionnaires distributed to 80 students of English Education Study Program, with follow-up interviews.

Those 15 ICT applications accessed by English students at the University of Bengkulu have the percentage that shows how often it is accessed in English learning. The results are Microsoft PowerPoint (26\%), Google Classroom (38\%), Google Meet (10\%), Zoom (78\%), WhatsApp (33\%), YouTube (46\%), Email (2\%), Elearning (67\%), Pdf (32\%), Google Translation (12\%), Grammarly (10\%), Online Dictionary (18\%), Google Search (19\%), Microsoft Word (8\%) and Google Drive (2\%). Thus, the most frequently used by students was Zoom and the most rarely used by students was Google Drive in English learning.

Table 1 The result of students' access to ICT application

\begin{tabular}{|c|c|c|c|}
\hline \multirow[t]{2}{*}{ No } & \multirow{2}{*}{$\begin{array}{c}\text { Name of ICT } \\
\text { Application }\end{array}$} & \multicolumn{2}{|c|}{ Total } \\
\hline & & $\mathbf{F}$ & $\mathbf{P}$ \\
\hline 1 & Microsoft Power Point & 21 & $26 \%$ \\
\hline 2 & Google Classroom & 31 & $38 \%$ \\
\hline 3 & Google Meet & 8 & $10 \%$ \\
\hline 4 & Zoom & 62 & $78 \%$ \\
\hline 5 & Whatsapp & 26 & $33 \%$ \\
\hline 6 & Youtube & 36 & $46 \%$ \\
\hline 7 & Email & 2 & $2 \%$ \\
\hline 8 & E-learning & 54 & $67 \%$ \\
\hline 9 & Pdf reader/nitro & 25 & $32 \%$ \\
\hline 10 & Google Translation & 10 & $12 \%$ \\
\hline 11 & Grammarly & 8 & $10 \%$ \\
\hline 12 & Online dictionary & 14 & $18 \%$ \\
\hline 13 & Google Search & 15 & $19 \%$ \\
\hline 14 & Microsoft Word & 6 & $8 \%$ \\
\hline 15 & Google Drive & 2 & $2 \%$ \\
\hline
\end{tabular}

The total score was from the calculation of ICT applications accessed by students in reading, writing, listening and speaking class. The data provided 15 ICT applications accessed by English students in English learning at the University of Bengkulu.

From the data, researcher found that Pdf reader/nitro was frequently accessed by students in reading class. Google Meet and Google Translation were seldom used by students in reading class. YouTube, Email, Grammarly, Microsoft Word and Google drive were never used by students in reading class.

In writing class, E-learning was frequently accessed by students. Zoom, Email and Google Search were seldom used in writing class and Google Meet and Google Drive were not used in writing class.

In listening class, YouTube was frequently accessed by students. Microsoft PowerPoint, Google Translation, Online Dictionary and Google Drive were seldom used in listening class. Meanwhile, Email, pdf, Grammarly and Microsoft Word were never used in listening class.

In speaking class, Zoom was frequently accessed by students. Google Classroom, Email, E-learning, Grammarly, Online Dictionary, Google Search and Google Drive were seldom used by students in speaking class. Moreover, Pdf and Microsoft Word were never used by students in speaking class.

Researcher also concluded that those applications were varied because of some reasons. First, they are from different classes, so they have different lecturers who have different teaching methods and the ICT application used certainly. As the following interview result;

P1 : I am from 7A. I usually use google translation. I also like using Udictionary (online dictionary).

$P 2$ : I am from $7 A$. I usually use Google Translation.

$P 3$ : I am from $7 B$. I usually use PDF.

P6 : I am from 7C. I usually use PowerPoint and WhatsApp.

$P 9$ : I am from 5B. I usually use Zoom in reading class. 
As evidenced above, the second reason for many types of ICT application accessed by students was caused by students' need in learning. For instance, P1 used both Google Translation and Online Dictionary, meanwhile P2 only used Google Translation.

Also, researcher can conclude another reason why there are many types of ICT applications accessed was because those applications were accessed by turns as long as the teaching and learning process in certain reading class of every semester. The use of some ICT applications was to vary the teaching and learning method managed by the lecturer. Researcher found that in one class, interviewee had different explanations about the ICT application used in the class. As the interview result below:

P3 : I am from 7B. I usually use Pdf. My lecturer orders me to read the material in Pdf, then we make a summary of it.

P5 : I am 7B. I usually use Google Translation. I use it to translate the meaning of English words in textbooks.

P7 : I am from 5A. I usually use Google Translation in reading class. I use it to translate the dialogue that is ordered to be read by the lecturer. We must find the meaning of unknown English words.

P12: I am from 5A. I usually use PowerPoint in reading. Lecturer delivers the materials through Power Point. We are also given the material in an e-book which is shared by the lecturer.

The researcher did the research to students of English Education Study Program at the University of Bengkulu from the academic year 2017 to 2020, so there are 4 types of academic year which consisted of 3 classes of 2017, 2 classes of 2018, 3 classes of 2019 and 3 classes of 2020. The total is 11 classes. Therefore, the ICT application types must be variety.

Next, researcher described the answer of RQ2 namely about how far ICT application helps students in mastering English language skill. The data were from a questionnaire and follow-up interview about students' perception towards how far ICT application helps students in mastering English language skills. The results are followed by elicitations from interviews to complement results from the questionnaire.

Table 2 English students' perceptions on the use of ICT application

\begin{tabular}{|c|c|c|c|c|c|c|c|}
\hline \multirow[t]{2}{*}{ No } & \multirow[t]{2}{*}{ Statement items } & \multicolumn{2}{|c|}{$\begin{array}{c}\text { Positive } \\
\text { perception }\end{array}$} & \multicolumn{2}{|c|}{ Neutral } & \multicolumn{2}{|c|}{$\begin{array}{c}\text { Negative } \\
\text { perception }\end{array}$} \\
\hline & & $\mathbf{F}$ & $\mathbf{P}$ & $\mathbf{F}$ & $\mathbf{P}$ & $\mathbf{F}$ & $\mathbf{P}$ \\
\hline 1 & Study English more effectively & 58 & $72 \%$ & 13 & $16 \%$ & 9 & $11 \%$ \\
\hline 2 & Improve my reading skills & 63 & $79 \%$ & 12 & $15 \%$ & 5 & $7 \%$ \\
\hline 3 & Improve my writing skills & 53 & $67 \%$ & 20 & $25 \%$ & 7 & $9 \%$ \\
\hline 4 & Improve my speaking skills & 57 & $71 \%$ & 16 & $20 \%$ & 7 & $9 \%$ \\
\hline 5 & Improve my listening skills & 64 & $80 \%$ & 12 & $15 \%$ & 4 & $6 \%$ \\
\hline 6 & Master my grammar competence & 43 & $54 \%$ & 29 & $36 \%$ & 8 & $10 \%$ \\
\hline 7 & Acquire vocabulary better & 53 & $66 \%$ & 23 & $29 \%$ & 4 & $6 \%$ \\
\hline 8 & $\begin{array}{l}\text { English learning can be more fun with ICT } \\
\text { applications }\end{array}$ & 57 & $71 \%$ & 15 & $19 \%$ & 8 & $10 \%$ \\
\hline 9 & Gain access to more updated English materials & 70 & $88 \%$ & 7 & $9 \%$ & 3 & $4 \%$ \\
\hline 10 & Acquire pronunciation & 59 & $74 \%$ & 18 & $23 \%$ & 3 & $4 \%$ \\
\hline
\end{tabular}




\section{Understand English learning material easier $\quad 52 \quad 66 \% \quad 18 \quad 23 \% \quad 15 \quad 13 \%$}

The perceptions are divided into three kinds of perceptions namely positive, neutral and negative perception. The table 2 shows that the majority of students have positive perception to the statement that ICT can help students in mastering English language skill. As the evidence above, from the first statement until the last statement, the highest percentage in each statement item is all in the scale, namely $72 \%, 79 \%, 67 \%, 71 \%$, $80 \%, 54 \%, 66 \%, 71 \%, 88 \%, 74 \%$ and $66 \%$.

Thus, it can be concluded that ICT can help students in mastering 4 skills namely reading, writing, listening and writing skill. Also, it helps students to acquire grammar, vocabulary and pronunciation.

In terms of supporting the questionnaire result above, researcher also shows the result from interview. For instance, in reading skill, Participant 12 (P12) and Participant 15 (P15) stated their views in the interview section as below:

$R \quad$ : Do you think that ICT application helps you in mastering reading skill? Give your reason.

P12: Yes, I do. The application is practical in learning anywhere and whenever we want. We can practice reading skill freely.

P15 : Yes, I do. All the learning materials are completed in ICT application. Therefore, it is very useful. If we don't have material from ICT applications and the aids for doing tasks, it 's difficult for me to do English learning in the class. It's the main source of reading.

From the interview data, there are 20 participants of 24 participants who have the same positive perception toward using ICT application in mastering reading skill. 4 participants don't have positive perception namely P14 and P24 are neutral, and P16 and P21 are negative perception.

Next, there are 15 students of 24 participants that have positive perception towards using ICT application in mastering writing skills. 1 student is neutral and 8 students namely P1, P8, P10, P11, P12, P20, P22 and P23 are negative perception. For instances, Participants 13 and 19 stated their views below;

$R$ : Do you think that ICT applications help you in mastering writing skill? Give your reason.

P13 : Yes, I do. In writing, the application provides the completed material. I can learn as much as possible in Google.

P19: Yes, I do. By using application, my grammar can be checked automatically or other word formation errors.

In listening skill, 21 students of 24 interview participants have positive perception towards using ICT application in mastering listening skill. P19, P23 and P24 are negative perception. As the example of opinion stated by $\mathrm{P} 2$ below;

$R$ : Do you think that ICT application helps you in mastering listening skill? Give your reason.

P2 : Yes, I do. It really helps me to familiarize English words pronounced by native speakers directly from YouTube Channel. I can be familiar with the English word pronunciation. The more I listen, the more I am familiar with English. I can access the audio or video as much as possible and anywhere.

P13 : Yes, I do. It helps me to master listening skill. I can practice my listening skill continuously during the class or out of the class. I like to repeat the video or audio till I get the information. It is more intensive. Meanwhile, in offline class, we just have three times repetition in listening to the audio or video.

Also, in speaking skill, researcher found that majority of students are positive perception towards using ICT application in mastering speaking skill. There are 16 students of 24 participants who are positive on it. P5, P12, P16, P19, P20, P22, P23 and P24 are negative on it. For instance, P1 and P3 stated their opinions in interview section below;

$R \quad$ : Do you think that ICT application helps you in mastering speaking skill? Give your reason.

P1 : Yes, I do. It really helps me in mastering Speaking skill. When I am speaking through YouTube, I can feel that my English can improve more. My confidence is also built. I am eager to master my speaking skill. I can speak English freely and flexibly.

P3 : Yes, I do. I like practicing my English from listening to the native speaker's pronunciation. I usually watch YouTube videos of native speakers, then I try to imitate them in pronouncing the words as similar as I can. Thus, I can try to speak English with appropriate pronunciation. 
In grammar, students who have positive perception are 13 students of 24 participants. P14 is neutral and P2, P8, P10, P11, P15, P16, P17, P20, P22 and P24 are negative perception. Example is as the interview evidence from $\mathrm{P} 3$ and $\mathrm{P} 18$ below;

$R \quad$ : Do you think that ICT applications help you to master grammar competence? Give your reason.

P3 : Yes, I do. It helps me so much. I use Grammarly to check my Grammar. It helps me to correct my grammar and learn Grammar.

P18: Yes, I do. I can understand the grammar material in application. We use Google Meet and I think that using Google meet in explaining the material is the same as in the offline class.

In vocabulary, there are 23 students' positive perception of 24 participants. 1 student is neutral. It means that majority of students agree that ICT application helps students to acquire vocabulary. As the example is stated by $\mathrm{P} 18$ and $\mathrm{P} 20$ below;

$R \quad$ : Do you think that ICT applications are able to acquire vocabulary better? Give your reason.

P18: Yes, I do. In doing the task, I always translate the words from Indonesian to English or English to Indonesian in an online dictionary such as Udictionary. Therefore, I get new vocabularies indirectly.

P20: Yes, I do. I usually use online dictionaries such as Udictionary or Kamusku. Therefore, I get new vocabularies flexibly and fast. The words are more than printed dictionaries.

Then, 18 students of 24 participants are positive perception towards using ICT application to acquire pronunciation. P14, P16, P20, P22, P23, P24 are negative perception. It can be seen on the interview result below from P3 and P18;

$R \quad$ : Do you think that using ICT application helps you to acquire pronunciation better? Give your reason.

P3 : Yes, I do. Relate to Speaking skill. As I mentioned before, I usually use YouTube to improve my pronunciation and my speaking as well.

P18: Yes, I do. In doing tasks, I usually use an online dictionary to find out the meaning. Beside it, the online dictionary provides the pronunciation. Therefore, I learn both vocabulary and pronunciation in an online dictionary.

Secondly, researcher concluded that the use of ICT application is effective in English teaching and learning. As the evidence above, researcher found that the use of ICT applications can help students to master English language skills. This is related to the effectiveness of ICT application used in English teaching and learning in the class. As the respondents stated in the interview result below:

$R$ : Do you think that using ICT application is effective in English teaching and learning? Does it make you understand easier, have more fun learning, motivate you and have the updated material? Give your reason.

P2 : Yes, I do. For example, when I am in the last class, I am bored of studying. The application can be media for the lecturer to deliver the material like using video from Youtube. It is interesting for us as students.

P3 : Yes, I do. All of the English learning sources are from ICT application. The English learning materials are from ICT application. Especially in English learning, we need the technology to find the information about that foreign language. Native speakers are not near in our learning environment. They are from another country. We can get the knowledge from them through ICT application. They deliver their language and knowledge about English in ICT application. It is a main media in English teaching and learning.

From the interview data, there are 15 students stated that using ICT application is effective in English learning. P14 P18, P19, P20, P23, P24 are neutral and P12, p16, p22 are negative perception.

The researcher concluded that the use of ICT application in English teaching and learning can help students to master the English language skills because of some reason. They are namely the learning sources are mostly from ICT application so they have many sources to enrich their knowledge more, the ICT application is practical so students can study anywhere and whenever they want fast and easily, ICT application is interesting and it is also motivating students to learn.

In addition, students also have the neutral perception and negative perception. The reason for effective or ineffective ICT application used in teaching and learning depends on lecturer, environment and students. Students with neutral perception thought that ICT application is useful for English learning but it can be 
effective depending on lecturer, students and environment. Meanwhile, students with negative perception thought that the use of ICT application is not useful for them and ineffective in English teaching and learning.

The students who disagree are majority from the academic year 2020 and 2019. They have mostly online classes. Especially in the academic year 2020, they haven't studied in the classroom yet. They just have online classes along their first semester now.

They said that lecturer doesn't use the appropriate ICT application and the teaching method. For example, P16 said that in reading class, the reading material in application is difficult to be understood. We just do the task without lecturer's feedback. There is no explanation from the lecturer. It relates to the lecturer. The use of ICT application should be followed by lecturer's guidance. Then, P22 said that the lecturer seldom attends the speaking class.

Also, they said the problem of signal affects them to access the ICT application well in learning English. It is the fact of online class. For example, P19 said that presentation using zoom is not good because the signal affects the quality in delivering the information. The information is usually unclear to the audience.

Moreover, related to the effect of online class, the cause of ineffectiveness of ICT application used in teaching and learning is also in students. Students' characteristics affect the teaching and learning. The characteristics are like students' motivation, control and independence. For example, P21 agrees that ICT application helps her to master grammar because she can learn more grammar material in Google, meanwhile P22 disagrees because she just hangs on lecturer's guidance to make her understand about grammar.

Therefore, the perception towards the use of ICT application in teaching and learning is effective depends on lecturer and students to manage them. Lecturers, students and ICT applications as teaching and learning media have the role to create the effectiveness of teaching and learning processes. The learning system online is also the supporting factor that causes the ineffectiveness of ICT application nowadays.

\subsection{Discussion}

This research aimed to find out students' access to ICT application in learning English and how far ICT application helps students in mastering English language skills experienced by students of English Education Study program at the University of Bengkulu. The findings are, first, English students at the University of Bengkulu accessed 15 types of ICT application overall and second, students agree that ICT application helps students in mastering English language skills.

The fact that students of English Education Study Program access 15 types of ICT applications in English learning. Those applications are Microsoft PowerPoint, Google Classroom, Google Meet, Zoom, WhatsApp, YouTube, Email, E-learning, Pdf, Google Translation, Grammarly, Online Dictionary, Google Search, Microsoft Word and Google Drive. Those 15 ICT applications are accessed by students in English learning because of lecturers' driven to use those applications and students' need.

For instance, lecturers' driven in reading class is using PowerPoint and WhatsApp. P16 said that we usually use Power Point to do presentation of the material and the electronic book is shared by WhatsApp group by lecturer. Then, P1 and P2 said that they usually use google translation and online dictionary in the class to know the meaning of unknown English words. Therefore, they usually use online dictionary as their need.

From the data, researcher found the best five ICT applications which are frequently used by students are Zoom, E-learning, YouTube, Google Classroom and WhatsApp. The most frequently used by students is Zoom in English learning. Zoom was frequently used because students can experience face to face interaction with other students and lecturer as virtual classroom. Every class of reading, writing, listening and speaking can use zoom to do learning process.

Meanwhile, the best five ICT applications which are rarely used by students are Google Meet, Grammarly, Microsoft Word, Email and Google Drive. The most rarely used by students is Google Drive in English learning. Students use Google Drive to save their video and share the link to lecturer. It's rarely used because most students familiarly use YouTube to save and share the video practically.

In reading class, students usually accessed 10 types of ICT applications namely Microsoft PowerPoint, Google Classroom, Google Meet, Zoom, WhatsApp, E-Learning, Pdf Reader/Nitro, Google Translation, Online Dictionary, and Google Search. From those applications, Pdf reader/nitro is frequently accessed by students in reading class. Students said that Pdf is accessible and practical to be used than using textbook in reading class.

SALTeL Vol. 4, No. 2, 2021: $37-48$ 
In writing class, students usually accessed 13 types of ICT applications namely Microsoft PowerPoint, Google Classroom, Zoom, WhatsApp, YouTube, Email, E-learning, Pdf, Google Translation, Grammarly, Online Dictionary, Google Search and Microsoft Word. From those applications, E-learning is frequently accessed by students in writing class. In interview section, students said that E-learning is a complete medium where they got the teacher's instruction, the material (e-book or video) and the task on it.

In listening class, students usually accessed 11 types of ICT applications which are Microsoft PowerPoint, Google Classroom, Google Meet, Zoom, WhatsApp, YouTube, E-learning, Google Translation, Online Dictionary, Google Search and Google Drive. From those applications, YouTube is frequently accessed by students in listening class. Students said that in the class they usually take the listening learning material from YouTube and they can practice their listening skill directly from the audio or video of native speaker at home. It can be used by them freely as much as possible.

In speaking class, students usually accessed 13 types of ICT applications which are Microsoft PowerPoint, Google Classroom, Google Meet, Zoom, WhatsApp, YouTube, Email, E-learning, Google Translation, Grammarly, Online Dictionary, Google Search and Google Drive. From those applications, Zoom is frequently accessed by students in Speaking class.

In speaking, students need interaction. As (Kurniawan \& Rozimela, 2017) said that in teaching speaking, students need interaction among students and teacher in the classroom. Students said that Zoom is a appropriate medium to create the virtual classroom in order to change real-life classroom. They can practice their speaking skill directly through zoom where lecturer and other students can listen carefully and pay attention to him or her.

In addition to detailed information about students' access to ICT applications in learning English, researcher did the interview to 24 interviewees. It found the fact from the interview; researcher concluded those applications are varied because of some reasons.

Firstly, the participants are from different classes, so they have different lecturers who have different teaching methods and the ICT application used certainly. The researcher did the research to students of English Education Study Program at the University of Bengkulu from the academic year 2017 to 2020, so there are 4 types of academic year which consisted of 3 classes of 2017, 2 classes of 2018, 3 classes of 2019 and 3 classes of 2020. The total is 11 classes.

The second reason for many types of ICT applications accessed by students was caused by students' need in learning. They can use some applications to learn English. For instance, P1 used both Google Translation and Online Dictionary in reading class, meanwhile P2 only used Google Translation in reading class.

Another reason is because those applications were accessed by turns as long as the teaching and learning process in certain reading class of every semester. The use of some ICT applications was to vary the teaching and learning method managed by the lecturer. Researcher found that in one class, interviewee had the different explanation about the ICT application used in the class and the teaching and learning method.

This research also found that ICT application can help students in mastering English language skills. Most students agree that ICT application is effective to help students mastering English language skills. The research result shows not completely $100 \%$ students agree but the majority of respondents agree about that. It means that ICT applications can be helpful for students or not.

Researcher found that the use of ICT application in English teaching and learning can help students to master the English language skills because of some reason namely the learning sources are mostly from ICT application so they have many sources to enrich their knowledge more, the ICT application is practical so students can study anywhere and whenever they want fast and easily, ICT application is interesting and it is also motivating students to learn. Therefore, the use of ICT application is effective in English teaching and learning.

According to UNESCO (2003), ICT helps teachers to gain material or information as the lesson. All learning sources are mostly in ICT. It offers people freedom to send and receive information efficiently across diverse geographic locations. Many teachers find that students are motivated to learn when they can use technology to present the results of a rich project or activity.

Meanwhile, for students with the neutral perception thought that ICT application can be effective or ineffective ICT application used in teaching and learning depending on lecturer. They said that ICT application is useful for English learning but it can be effective depending on lecturer. As P12 stated that the application has facilitates the completed material, but lecturer's teaching method must be appropriate to 
application as well. Then, P14 said that she can improve her grammar a little bit by using ICT application, so she'd rather need lecturer's explanation in the classroom.

Students with neutral perception thought that ICT application is useful for English learning depending on environment. P24 said that so far, because of this pandemic, the ICT application is beneficial in online teaching and learning. But it is more effective to use ICT application in offline class. It is more intensive and clearer than in online class. Lecturer's explanation can give us the better understanding.

Students with neutral perception thought that ICT application is useful for English learning but it depends on students. P14 said that if each student is active and serious in learning using ICT application, it will make English learning be effective. Then, P24 also said that the learning application makes her independent to learn during the pandemic.

Also, the use of ICT applications can't help students to master the English language skills because it is ineffective to be used in English teaching and learning. The reason is gained through interviews between researcher and participants. It can be concluded that the reason for ineffective ICT application used in teaching and learning is because of lecturer, environment and students. The learning system online is also the supporting factor that causes the ineffectiveness of ICT application nowadays. Lubis \& Nopriansah (2018) said that effective and ineffective experiences of learning English are crucial thing.

Lecturer doesn't use the appropriate ICT application and the teaching method in online class. For example, P16 said that in reading class, the reading material in application is difficult to be understood. We just do the task without lecturer's feedback. There is no explanation from the lecturer. Also, P22 added that the lecturer seldom attends the speaking class. Kuhlman (2017) states that one of the core effective practices for English language learning is providing appropriate feedback on what students need to do better.

Problem of signal affects them to access the ICT application well in learning English. It is the fact of online class. For example, P19 said that presentation using zoom is not good because the signal affects the quality in delivering the information. The information is usually unclear to the audience. As Siddiquah \& Salim (2017) state that signal problem is one of the problems faced by the majority of the students.

Moreover, related to the effect of online class, the cause of ineffectiveness of ICT application used in teaching and learning is also in students. Students' characteristics affect the teaching and learning. The characteristics are like students' motivation, control and independence. Montiel-Chamorro (2018) states one of the core effective practices for online English language learning is on student characteristics. Students' characteristics may play an important role in the success or failure of online courses.

Based on the discussion above, the researcher concluded that the ICT applications which are accessed by students are varied. It depends on the lecturer and students' needs in the class. As a result, the use of ICT application in English teaching and learning is effective and helps students in mastering English language skill. It also depends on how the lecturer and students use it to achieve effective English learning.

As discussed above, researcher found research about all ICT application types accessed by English students at the University of Bengkulu and how far ICT application helps students in mastering English language skills. Meanwhile, the previous studies which conducted the research related to ICT application haven't found anything about it yet.

Previous studies have already found about students' access to ICT namely hardware and software. For instance, Alfarwan, (2019) found about students' access to electronic device (e. g computer, smart phone and television), Siddiquah \& Salim (2017) found students' access to ICT (computer and internet facilities) and the problems faced by students while using ICT in University. Then, Margareta et al (2017) also found software or application namely ICT-Based English Material which improves students' reading ability.

Then, they found about students' attitude, perception and expectation towards ICT in general. For instances, Jariah et al (2017) proved that ICT was effective for students mastering vocabulary and Al Arif (2019) found that students showed positive attitudes towards ICT use in learning English. Students perceived that ICT was important to improve their English skills and they expected that teachers were more frequently used ICT tools in teaching and learning process.

\section{Conclusion}

After doing the research and investigating the students' access to ICT and how far the use of ICT applications helps students in mastering English language skills experienced by students of English Education Study Program at the University of Bengkulu, researcher found two conclusions. 
First, the data indicate that there are 15 ICT applications accessed by English students at the University of Bengkulu. They are Microsoft PowerPoint, Google Classroom, Google Meet, Zoom, WhatsApp, YouTube, Email, E-learning, Pdf, Google Translation, Grammarly, Online Dictionary, Google Search, Microsoft Word and Google Drive.

Second, the use of ICT application is mostly effective and helps students in mastering English language skills. The majority of the students agree about that. The use of ICT application in English teaching and learning can help students to master the English language skills because of some reason namely the learning sources are mostly from ICT application so they have many sources to enrich their knowledge more, the ICT application is practical so students can study anywhere and whenever they want fast and easily, ICT application is interesting and it is also motivating students to learn. Therefore, the use of ICT application is effective in English teaching and learning.

However, it depends on how the lecturer and students use it to create an effective English learning. Lecturers, students and ICT applications have each important role to build effective English learning. The supporting factor that causes the ineffective English learning using ICT applications is the online learning system.

\section{References}

Adeosun, O. (2010). Quality basic education development in Nigeria: Imperative for use of ICT. Journal of International Cooperation in Education, 13(2), 193-211.

Al Arif, T. Z. Z. (2019). Indonesian university students' perception and expectation towards ICT use in learning English as a foreign language. IJELTAL (Indonesian Journal of English Language Teaching and Applied Linguistics), 4(1), 133-145.

Alfarwan, S. (2019). University student access to and use of electronic devices: A latent English language learning potential. Teaching English with Technology, 19(1), 102-117.

Ammanni, S., \& Aparanjani, U. (2016). The role of ICT in English language teaching and learning. International Journal of Scientific and Engineering Research, 7(7), 1-7.

Annamalai, N. (2017). Exploring Students Use of Facebook in Formal Learning Contexts. Indonesian Journal of EFL and Linguistics, 2(2), 91-106.

Bafadal, I. (2004). Manajemen perlengkapan sekolah teori dan aplikasinya. Jakarta: Bumi Aksara.

Creswell, J. W. (2014). A concise introduction to mixed methods research. SAGE publications.

Galavis, B. (1998). Computers and the EFL class: Their advantages and a possible outcome, the autonomous learner. English Teaching Forum, 36(4), 27.

Jariah, A., Safnil, S., \& Irwan, K. (n.d.). A NEED ANALYSIS ON MASTERING ENGLISH VOCABULARY USING INFORMATION AND COMMUNICATION TECHNOLOGY (ICT) FOR SENIOR HIGH SCHOOLS.

Joshi, K. R., \& Poudel, G. P. (2019). Role of ICTs in Promoting Learner Independence and Motivation in English Language Classes. Interdisciplinary Research in Education, 4(1), 67-76.

Kudsiyah, Y. (2009). Analysis of some causal factors of students' problem in learning English:(a casr study of second grade students of SMP Al-Inayah, Karawang).

Kuhlman, K. (2017). Best Practices in Foreign Language Learning.

Kurniawan, I., \& Rozimela, Y. (2017). THE EFFECT OF STUDENT TEAMS-ACHIEVEMENT DIVISION (STAD) TECHNIQUE TOWARD STUDENTS'SPEAKING SKILL AND CLASS PARTICIPATION. Journal of English Education and Teaching, 1(1), 35-47.

Lase, D. (2019). Education and industrial revolution 4.0. JURNAL HANDAYANI PGSD FIP UNIMED, 10(1), $48-62$.

Lowther, D. L., Inan, F. A., Daniel Strahl, J., \& Ross, S. M. (2008). Does technology integration "work" when key barriers are removed? Educational Media International, 45(3), 195-213.

Lubis, A. A., \& Nopriansah, H. (2018). A., Nasution, SS, \& Yusuf, M. (2018). Students' Experiences of Learning English in Indonesia: Some Effective and Ineffective Ways. Abjadia: International Journal of Education, 3(2), 100-111.

Margareta, M., Safnil, S., \& Koto, I. (2017). A Need Analysis on Ict-based English Material for Teaching and Learning Of Reading For High School Students In South Bengkulu. JOALL (Journal of Applied Linguistics and Literature), 2(2), 35-46. 
Montiel-Chamorro, M. L. (2018). Comparing online English language learning and face-to-face English language learning at El Bosque University in Colombia.

$\begin{array}{lllll}\text { Oxford University } & \text { Press. } & \text { (2016). Access } & \text { definition. }\end{array}$ http://www.oxforddictionaries.com/definition/english/access

Sabri, K. S., \& Emuas, A. H. M. (1999). The relationship between school laboratory experiments and academic achievement of Palestinian students in introductory university science courses. Research in Post-Compulsory Education, 4(1), 87-96.

Schoepp, K., \& Erogul, M. (2001). Turkish EFL students' utilization of information technology outside of the classroom. TEFL Web Journal, 1(1), 14.

Selinger, M. (2000). Information and communication technology in schools. Imfundo Knowledge Bank. Retrieved October, 25, 2009.

Siddiquah, A., \& Salim, Z. (2017). The ICT facilities, skills, usage, and the problems faced by the students of higher education. EURASIA Journal of Mathematics, Science and Technology Education, 13(8), 49874994.

Suryani, A. (2010). ICT in education: Its benefits, difficulties, and organizational development issues. Jurnal Sosial Humaniora (JSH), 3(1), 13-33.

Sutrisno, S. (2012). Kreatif Mengembangkan Aktivitas Pembelajaran Berbasis TIK. Referensi.

UNESCO. (2003). Information and communication technologies in teacher education: a planning guide | United Nations Educational, Scientific and Cultural Organization. http://www.unesco.org/new/en/communication-and-information/resources/publications-andcommunication-materials/publications/full-list/information-and-communication-technologies-inteacher-education-a-planning-guide/

UNESCO Office Bangkok and Regional Bureau for Education in Asia and the Pacific. (2007). Technologies for education: achievements and future initiatives in the Asia-Pacific Region - UNESCO Digital Library. https://unesdoc.unesco.org/ark:/48223/pf0000142239

Westera, W., \& Sloep, P. B. (2001). The future of education in cyberspace. Cyber Education: The Future of Distance Learning. Larchmont, NY: Mary Ann Liebert, Inc, 115-136. 